\title{
FAKTOR -FAKTOR YANG MEMPENGARUHI KUALITAS AIR MINUM PADA DEPOT AIR MINUM DI KOTA BENGKULU TAHUN 2012
}

\author{
Jubaidi, Sri Mulyati, Ps.Kurniawati,*** \\ Poltekkes Kemenkes Bengkulu, Dosen Jurusan Kesling Jl. Indragiri 3 Padang Harapan \\ Poltekkes Kemenkes Bengkulu, Dosen Jurusan Kebidanan JI. Indragiri 3 Padang Harapan
}

\begin{abstract}
Drinking water quality is one of the basic needs of society. In fulfilling its needs, the community has sought a way to buy a gallon of drinking water refill at a cheap price. The purpose of this study was to determine the factors that affect drinking water quality in drinking water depots in the city of Bengkulu. This study is a survey research with cross sectional approach, a sample size in this study as many as 163 samples. Primary data processed by the regression test followed by logistic regression test.The results showed that the dominant factor is the effect of drinking water treatment process with a value of $\mathrm{p}=0.000$ and Exp. $\mathrm{B}=4.454$. Recommended for drinking water depots entrepreneurs in drinking water treatment processes to use micro filters with a diameter smaller than viruses, provide training for employees or managers of drinking water and perform maintenance of drinking water processing components on time and as well as the guidance and supervision on a regular basis by the government.
\end{abstract}

\begin{abstract}
Abstrak : Air minum yang berkualitas merupakan salah satu kebutuhan pokok masyarakat. Dalam memenuhi kebutuhannya, masyarakat telah berupaya dengan cara membeli air minum galon isi ulang dengan harga yang murah. Tujuan dalam penelitian ini adalah untuk mengetahui factorfaktor yang mempengaruhi kualitas air minum pada depot air minum di Kota Bengkulu. Penelitian ini merupakan penelitian survey dengan pendekatan cross sectional, besar sampel dalam penelitian ini sebanyak 163 sampel. Data primer diolah dengan uji regresi dan dilanjutkan dengan uji regresi logistik.Hasil penelitian menunjukkan bahwa faktor yang dominan berpengaruh adalah proses pengolahan air minum dengan nilai $\mathrm{p}=0,000$ dan Exp. $\mathrm{B}=4$ 4,454.Disarankan bagi pengusaha depot air minum dalam proses pengolahan air minum untuk menggunakan mikro filter yang berdiameter lebih kecil dari virus, memberikan pelatihan bagi karyawan atau pengelola air minum dan melakukan pemeliharaan terhadap komponen pengolah air minum tepat waktu dan adanya pembinaan serta pengawasan secara rutin oleh pemerintah.
\end{abstract}

Kata Kunci : Air Minum dan Depot Air Minum

Pengadaan air bersih untuk kepentingan rumah tangga seperti untuk air minum, air mandi, dan sebagainya harus memenuhi persyaratan yang sudah ditentukan peraturan internasional (WHO) ataupun peraturan nasional. Dalam hal kualitas air bersih di Indonesia harus memenuhi persyaratan yang tertuang di dalam Peraturan Menteri Kesehatan RI No.492/Menkes /Per/IV/2010, dimana setiap komponen yang diperkenankan berada di dalamnya harus memenuhi syarat kualitas air minum.

Air bersih yang layak diminum, kian langka di perkotaan. Sungai-sungai yang menjadi sumbernya sudah tercemar berbagai macam limbah, mulai dari buangan sampah organik, rumah tangga hingga limbah beracun dari industri. Air tanah sudah tidak aman dijadikan bahan air minum karena telah terkontaminasi rembesan dari tangki septik maupun air permukaan.

Itulah salah satu alasan mengapa air minum dalam kemasan yang disebutsebut menggunakan air pegunungan banyak dikonsumsi. Namun, harga air minum dalam kemasan dari berbagai merek yang terus meningkat membuat konsumen mencari alternatif baru yang murah.

Air minum yang diproduksi oleh depot air minum menjadi jawabannya. Air minum yang bisa diperoleh di depot-depot itu harganya bisa sepertiga dari produk air minum dalam kemasan yang bermerek. Karena itu banyak rumah tangga beralih pada layanan ini. Hal inilah yang me- 
nyebabkan depot air minum bermunculan. Keberadaan depot air minum terus meningkat sejalan dengan dinamika keperluan masyarakat terhadap air minum yang bermutu dan aman untuk dikonsumsi. Meski lebih murah, tidak semua depot air minum terjamin keamanan produknya. Hasil pengujian laboratorium yang dilakukan Badan Pengawas Obat dan Makanan atas kualitas depot air minum di Jakarta (Kompas, 2003) menunjukkan adanya cemaran mikroba dan logam berat pada sejumlah contoh air minum. Menurut hasil pengujian laboratorium kesehatan Kota Bengkulu terhadap 113 depot air minum bahwa sebanyak $50 \%$ tidak memenuhi syarat kesehatan, dengan demikian bahwa air minum yang dikonsumsi masih mengandung mikroorganisme penyakit menular.

Berdasarkan uraian di atas, maka tujuan yang ingin dicapai dalam penelitian ini 1) Untuk mengetahui pengaruh proses pengolahan air minum terhadap kualitas air minum pada depot air minum di Kota Bengkulu. 2) Untuk mengetahui pengaruh pemeliharaan komponen pengolahan air minum terhadap kualitas air minum pada depot air minum di Kota Bengkulu. 3) Untuk mengetahui pengaruh pelatihan yang diikuti oleh pengusaha atau pengelola depot air minum terhadap kualitas air minum pada depot air minum di Kota Bengkulu. 4) Untuk mengetahui faktor yang paling berpengaruh terhadap kualitas air minum pada depot air minum di Kota Bengkulu

\section{BAHAN DAN CARA KERJA}

Untuk memperoleh data yang valid, penelitian ini menggunakan metode survey dengan rancangan cross sectional. Kuesioner sebagai instrumen pengumpul data dan sampel air minum dari masingmasing depot air minum. Populasi dalam penelitian ini adalah seluruh depot air minum yang ada di Kota Bengkulu sebanyak 276 depot air minum. Sampel dalam penelitian ini sebanyak 163 sampel, sampel diambil dengan teknik random sampling. Pengisian kuisioner dilakukan oleh responden di pandu oleh mahasiswa termasuk pengambilan sampel air minum yang dilakukan oleh mahasiswa Jurusan Kesehatan Lingkungan Semester V, kemudian dilakukan pemeriksaan bakteriologis dilaboratorium Kesehatan Kota Bengkulu.

Analisa data dilakukan secara deskriptif untuk data unifariat dan analisis bifariat serta uji multifariat untuk melihat pengaruh yang paling dominan terhadap variable dependen (kualitas air minum)

\section{HASIL}

Pengumpulan data dilakukan dengan menggunakan kuesioner dan dilanjutkan dengan pemeriksaan sampel air minum di laboratorium Kesehatan Kota Bengkulu terhadap163 responden pemilik depot air minum (DAM).

Berdasarkan tabel di bawah ini, menunjukan bahwa pengelola DAM melakukan pengolahan air minum dilakukan dengan tidak lengkap sebanyak 55,2\%. Hasil analisis statistik diperoleh $p$-value $(0,000)$ lebih kecil dari $\alpha$, yang berarti proses pengolahan air minum berpengaruh secara nyata dalam menghasilkan air minum yang berkualitas baik.

Sebanyak $63,2 \%$ depot air minum tidak teratur dalam pemeliharaan komponen pengolah air minum. Hasil uji statistik diperoleh $p$-value $(0,000)$ lebih kecil dari $\alpha$, yang berarti pemeliharaan komponen pengolah air minum bepengaruh secara nyata dalam menghasilkan air minum yang berkualitas baik.

Sebanyak $56,4 \%$ pengelola depot air mi-num tidak terlatih. Hasil uji statistik diperoleh $p$-value $(0,000)$ lebih kecil dari $\alpha$, yang berarti tenaga pengelola air minum terlatih berpengaruh secara nyata dalam menghasilkan air minum yang berkualitas baik.

Sebanyak $63,2 \%$ depot air minum menghasilkan air minum yang tidak memenuhi syarat kesehatan. 
Tabel 1 Persentase Proses Pengolahan Air Minum, Pemeliharaan Komponen Pengholah Air Minum, Pelatihan yang diikuti oleh Pengelola Depot Air Minum, Kualitas Air Minum yang di Produksi Depeot Air Minum Di Kota Bengkulu Tahun 2011

\begin{tabular}{lcc}
\hline \multicolumn{1}{c}{ Variabel } & Jumlah $(\mathbf{n}=\mathbf{1 6 3})$ & Prosentase (\%) \\
\hline Proses Pengolahan Air Minum & 73 & 44,8 \\
Lengkap & 90 & 55,2 \\
Tidak Lengkap & & 36,8 \\
Pemeliharaan Komponen DAM & 60 & 63,2 \\
Teratur & 103 & 43,6 \\
Tidak Teratur & & 56,4 \\
Pelatihan Pengelola DAM & 71 & 36,8 \\
Dilatih & 92 & 63,2 \\
Tidak dilatih & & \\
KualitasAir Minum & 60 & \\
Memenuhi Syarat & 103 & \\
Tidak Memenuhi Syarat & & \\
\hline
\end{tabular}

Hasil analisis statistik terhadap faktorfaktor yang mempengaruhi kualitas air mi- num pada depot air minum di Kota Bengkulu disajikan pada tabel berikut:

Tabel 2. Analisis Pengaruh Proses Pengolahan Air Minum, Pemeliharaan Komponen pengolah air minum dan pelatihan yang diikuti oleh Pengelola depot air minum terhadap Kualitas Air Minum pada Depot Air Minum di Kota Bengkulu 2011

\begin{tabular}{lccc}
\hline \multicolumn{1}{c}{ Variabel } & $\mathrm{X}^{2}$ & Exp (B) & $\mathrm{P}$ \\
\hline Pengolahan & 14,726 & 3,477 & 0,000 \\
Pemeliharaan & 13,098 & 3,392 & 0,000 \\
\multicolumn{1}{c}{ Pelatihan } & 12,585 & 3,165 & 0,000 \\
\hline
\end{tabular}

Berdasarkan hasil analisis statistik (bivariat) Tabel 5, menunjukkan bahwa ketiga variabel independen tersebut masingmasing mempunyai nilai $\mathrm{p}=0,000$ yang berarti ketiganya mempengaruhi kualitas air minum yang diproduksi depot air mi- num di Kota Bengkulu. Berdasarkan tabel 5 tersebut belum diketahui variable independen mana yang dominan mempengaruhi kualitas air minum, untuk itu dilakukan uji regresi logistik, yang hasilnya pada tabel berikut:

Tabel 3. Hasil Uji Regresi Logistik Antara Variable Independen Terhadap Variable Dependen (Kuallitas Air Minum Pada Depot Air Minum) di Kota Bengkulu)

\begin{tabular}{lccc}
\hline & Variabel & $\mathrm{P}$ & $\operatorname{Exp}(\mathrm{B})$ \\
\hline Pemeliharaan & 0,012 & 2,610 \\
Pengolahan & 0,000 & 4,150 \\
Pelatihan & 0,001 & 3,677 \\
\hline
\end{tabular}

Hasil uji statistik regresi logistik pada tabel 6 diperoleh p-value $(0,000)$ atau ni-lai $\operatorname{Exp}(B)=4,150$ yang berarti bahwa yang paling dominan mempengaruhi kualitas air minum pada depot air minum adalah pada tahapan proses pengolahan air minum, di banding variable pelatihan dengan p-value $(0,001)$ atau nilai $\operatorname{Exp}$ (B) 3,677.

Untuk melihat model dari uji regresi logistik guna melihat paling dominan antara proses pengolahan air minum dengan pelatihan bagi pengelola depot air minum, maka dilakukan uji regresi logistik model akhir.

Hasil uji statistik regresi logistik model terakhir pada tabel di bawah diperoleh nilai $\mathrm{p}=0,000<\alpha$, atau nilai $\operatorname{Exp} \mathrm{B}$ $(\mathrm{OR})=4,454 \quad$ yang berarti bahwa yang paling dominan dalam mempengaruhi kualitas air minum pada depot air minum adalah pada tahapan proses pengolahan air minum. 
Tabel 4. Hasil uji regresi logistik model terakhir antara Proses Pengolahan Air Minum dengan Pelatihan Tenaga Pengelola Depot Air Minum terhadap Kuallitas Air Minum pada Depot Air Minum di Kota Bengkulu

\begin{tabular}{lccc}
\hline & Variabel & P & Exp (B) \\
\hline Pelatihan & & 0,000 & 4,113 \\
Pengolahan & 0,000 & 4,454 \\
\hline
\end{tabular}

\section{PEMBAHASAN}

Proses pengolahan air minum pada depot air minum di Kota Bengkulu pada dasarnya sesuai dengan prinsip umum yaitu menggunakan peralatan filtrasi (filter pasir, filter karbon aktif, dan mikro filter) dan desinfektan (UV dan atau ozone). Proses pengolahan air minum yang dilakukan depot air minum di Kota Bengkulu sebagai berikut : Air baku (berasal dari air permukaan yang dilindungi) disimpan dalam tandon, air dari tandon dengan menggunakan pompa dialirkan ke filter pasir, air dari filter pasir dialirkan ke filter karbon aktif, air dari filter karbon aktif dialirkan ke beberapa filter cartridge/membrane RO, selanjutnya air di alirkan ke unit sterilisator Ultra Violet kemudian air siap dikonsumsi. Namun dalam proses pengolahan air baku menjadi air minum ada beberapa kegiatan tidak dilaksanakan dengan baik atau tidak lengkap sebanyak 55,2\%, seperti back wash yang seharusnya dilakukan setiap akan dan sesudah produksi air minum, back wash merupakan kegiatan untuk membersihkan seluruh filter dari kotoran dan endapan yang terdapat dalam filter. Sementara itu penggantian komponen seperti media filter pasir, media filter karbon aktif, filter cartridge, lampu Ultra Violet yang tidak berfungsi tidak diganti tepat pada waktunya sebanyak $63,2 \%$. Keadaan ini didukung pula oleh tenaga pengelola yang tidak terlatih sebanyak $56,4 \%$ dalam memproduksi air minum, sehingga depot air minum menghasilkan air minum yang tidak memenuhi syarat sebanyak $63,2 \%$ untuk dikonsumsi.

Berdasarkan hasil analisis statistik menunjukkan bahwa ketiga Proses pengolahan air minum, pemeliharaan komponen pengolahan air minum dan pelatihan yang dilakukan pengelola depot air minum, masing-masing diperoleh $p$-value $(0,000) \mathrm{le}$ - bih kecil dari $\alpha$, yang berarti ada peng-aruh yang bermakna antara proses peng-olahan air minum, pemeliharaan komponen pengolahan air minum dan pelatihan yang dilakukan pengelola depot air minum terhadap kualitas air minum yang di hasilkan oleh depot air minum di Kota Bengkulu.

Air permukaan yang dilindungi, yang digunakan sebagai air baku depot air minum di Kota Bengkulu merupakan salah satu sumber air minum yang rentan terhadap pencemaran dari limbah domestik (rumah tangga) dan limbah industri (Said, NI, 2006). Menurut Budiman (2006), menyatakan bahwa sumber air permukaan yang berasal dari air hujan telah mengalami pencemaran dari tanah dan sampah. Akibatnya terjadi aku mulasi polutan dalam air baku akan tinggi, hal ini menyebabkan beban pengolahan air baku menjadi air minum semakin berat.

Teknologi yang digunakan di depot air minum Kota Bengkulu secara teknis dapat menghasilkan air siap diminum dengan harga yang murah. Dengan menjamurnya bisnis air minum saat ini, permasalahan yang timbul adalah aturan yang legal masih belum ada sehingga perlindungan terhadap konsumen belum bias dipertanggungjawabkan. Karena bisnis air siap di minum telah dapat diterima pasar dengan baik (Said, NI, 2002), maka pengusaha depot air minum harus menerapkan teknologi sesuai standar yang ditetapkan oleh pemerintah (Kemenperindag RI, 2005).

Said, NI, dan Yudo,S, (2008), menyatakan bahwa bahaya atau resiko kesehatan manusia/masyarakat dapat terjadi akibat mengkonsumsi air minum yang tercemar atau kualitas air minum yang buruk dan penggunaan air yang tercemar untuk berbagai kegiatan sehari-hari seperti mencuci peralatan makanan dan minuman. Kualitas air baku depot air minum yang rendah sebagai akibat perubahan tataguna lahan di 
daerah hulu sampai ke hilir mengakibatkan konsentrasi polutan yang ada dalam air permukaan (sungai dan danau) menjadi lebih pekat sehingga terjadi penurunan kualitas air minum yang dihasilkan serta naiknya biaya produksi air minum. Sadtiwi (2004), mencatat dari hasil penelitian laboratorium IPB pada tahun 2002 dari 120 sampel air minum isi ulang di kota-kota besar sebanyak $16 \%$ mengandung bakteri Coliform.

Menurut Sulistyandari (2009), bahwa kualitas air minum di pengaruhi oleh proses pengolahan air minum dan pemeliharaan peralatan depot air minum isi ulang di Kabupaten Kendal. Athena dkk. (2004), menyatakan bahwa air minum yang diproduksi depot air minum di Jakarta, Tanggerang dan Bekasi masih mengandung bakteri E.Coli, sehingga air minum tersebut tidak memenuhi syarat untuk dikonsumsi. Demikian juga kualitas air minum yang diproduksi depot air minum (113 depot) di Kota Bengkulu hampir sebagian tidak memenuhi syarat kesehatan (Labkes Kota Bengkulu, 2010). Dengan masih tingginya kandungan bakteri E. Coli pada air minum yang diproduksi di depot air minum maka perlu dilakukan pengawasan yang ketat, karena bukan penyakit diare saja yang menimpa masyarakat tetapi penyakit lain yang lebih berbahaya seperti polio, hepatitis bahkan kanker (Said 2008). Untuk itu pemerintah daerah (Dinas Kesehatan Kota Bengkulu) perlu melakukan pengawasan terhadap depot-depot air minum yang ada di Bengkulu.

Berdasarkan hasil analisis multivariat model akhir menunjukkan bahwa proses pengolahan air minum dengan nilai Exp (B) $=4,454$ yang berarti bahwa tahapan proses pengolahan air minum merupakan kegiatan yang sangat penting dan menentukan bagi pengelola depot air minum dalam memproduksi air minum yang memenuhi syarat kesehatan, dengan kata lain semakin lengkap proses produksi maka semakin baik kualitas air minum yang dihasilkan.
Proses pengolahan air minum di depot air minum ditentukan oleh penggunaan mikrofilter yang berdiameter lebih kecil dari diameter bakteri atau virus. Secara umum di-ameter bakteri sebesar 0,5 $\mu-2,0$ $\mu$ (Alice, Betty dan Dannil, 2007) dan (Slid-eshare.com), dan diameter virus sebesar 20,0 nm (Wikipedia.com), jika pengusaha depot air minum di Kota Bengkulu menggunakan teknologi dengan filter cartridge berdiameter $0,5 \mu$, maka air minum yang diproduksi de-pot air minum masih mengandung bakteri dan virus karena diameter bakteri dan virus lebih kecil dari diameter filter yang digunakan. Untuk menghasikan air minum ya-ng berkualitas (secara bakteriologis) selayaknya para pengusaha depot air minum menggunakan teknologi mikro filter yang berdiameter lebih kecil dari diameter virus $(<$ $20 \mathrm{~nm}$ ) seperti membran reserve osmosis (filter RO) yang berdiameter $0,005 \mu$ $0,0001 \mu$, membrane RO dapat menghasilkan 99,99\% air murni, dengan menggunakan membrane ini tidak ada lagi bakteri dan virus bahkan zat kimia tertentu dalam air minum. Selain penggunaan mikrofilter tersebut kegiatan dalam proses pengolahan air minum adalah melakukan back wash sebelum dan sesudah produksi air minum selama 15 menit kemudian bilas selama 5 menit atau sampai air bersih dan jernih secara fisik.

Hasil analisis model akhir ini juga menunjukkan bahwa pelatihan mempunyai pengaruh yang bermakna dengan Exp (B) $=4,113$, berarti bahwa peran tenaga pengelola yang terlatih mempunyai peran penting dan menentukan dalam pengelolaan air minum, menurut Gomes (2003), bahwa pelatihan dapat meningkatkan kinerja pada suatu pekerjaan tertentu yang sedang menjadi tanggung jawabnya. Melalui pelatihan pengelola depot air minum menjadi lebih terampil dan lebih produktif, dengan demikian pelatihan yang diikuti oleh pengelola depot air minum dapat mempengaruhi kualitas air minum apabila dikelola oleh tenaga yang terampil dan ini merupakan hasil dari suatu proses trans- 
formasi dalam peningkatan kemampuan dalam melaksanakan tugas yang tercermin dalam sikap, disiplin dan etos kerja (Notoatmodjo, S.1991). Mangkuprawira (2011), menyatakan bahwa pelatihan merupakan proses mengajarkan pengetahuan dan keahlian tertentu serta sikap agar karyawan semakin terampil dan mampu melaksanakan tugas atau tanggung jawabnya dengan semakin baik.

\section{KESIMPULAN}

Berdasarkan hasil dan pembahasan, maka simpulan adalah :

1. Sebagian besar depot air minum di Kota Bengkulu diproses tidak menggunakan komponen pengolahan air minum yang lengkap.

\section{DAFTAR KEPUSTAKAAN}

Alice SW., Betty AF., Dannil FS., (2007), Diagnostic Microbiology, Nosby, Texas., USA, Edisi 12

Andrianto, TT., 2002. Audit Lingkungan, Global Pustaka Utama, Yogyakarta

Anoname, 2009. Manual Book Opertion, Water Treatment Palnt, CV. Asco Engineering, Jakarta

Athena, dkk., 2004, Kandungan Bakteri Total Coli dan E.Coli Air Minum dari Depot Air Minum Isi Ulang di Jakarta, Tanggerang dan Bekasi, Buletin Penelitian Kesehatan, Vol.32 No.4.

Chandra, B, 2007, Pengantar Ilmu Kesehatan Lingkungan, Jakarta, EGC

Cut Zurnali, 2004, Pengaruh Perlatihan dan Motivasi Terhadap Perilaku Produktif Karyawan pada Divisi Long Distance PT. Telkom Indonesia, Tbk, Tesis, Program Pascasarjana Unpad, Bandung

Depkes RI., 1996. Virologi Umum, Pusat Pendidikan Tenaga Kesehatan, Jakarta

Dinas Kesehatan Kota Bengkulu, 2009. Profil Kesehatan Kota Bengkulu

Gomes,. FC., 2003, Manajemen Sumber Daya Manusia, CV. Andi Offset, Yogyakarta.

Kementerian Kesehtan RI, 2010. Persyaratan Kualitas Air Minum, Jakarta

Kementerian Perindustrian dan Perdagangan, 2005. Buku Pedoman Operasional Depot Air Minum, Jakarta

2004. Syarat pendirian Depot Air Minum, Jakarta

Kompas. Com, 2011. Bakteri E.Coli Baru Lebih Mematikan, (Diakses pada 25Juli 2011)
2. Sebagian besar depot air minum di Kota Bengkulu tidak teratur dalam melakukan pemeliharaan komponen pengolahan air minum

3. Sebagian besar tenaga pengelola depot air minum di Kota Bengkulu tidak terlatih dalam pengolahan air minum

4. Terdapat pengaruh yang nyata dari ketiga variable independen pengolahan air minum, pemeliharaan komponen pengolah air minum dan pelatihan tenaga pengolah air minum terhadap kualitas air minum yang diproduksi oleh depot air minum di Kota Bengkulu, namun pengaruh yang paling dominan terjadi pada proses pengolahan air minum, terhadap kualitas air minum yang diproduksi oleh depot air minum di Kota Bengkulu

Mangkuprawira, TS,2011, Manajemen Sumber Daya Manusia Strategik, Ghalia Indonesia

Margono, 2010. Penyediaan Air Bersih, Surabaya

Mubarak dan Chayatin, 2009. Ilmu Kesehatan Masyarakat (Teori danaplikasi), Salemba Medika,Jakarta

Notoatmojo., S. 2003. Ilmu Kesehatan Masyarakat (Prinsip-prinsip Dasar), Renika Cipta, Jakarta 1991, Pengembangan Sumberdaya Manusia, Rineka Cipta, Jakarta

Radar Bengkulu, 2010. Kasus Diare di Kota Bengkulu

Sadtiwi, S., 2004. Kajian kualitas produksi air minum isi ulang pada depot air minum di Kota Kudus, Abstrak.

Said, NI., 1999. Kesehatan Masyarakat dan Teknologi Peningkatan Kualitas Air, BPPT, Jakarta 1999. Teknologi Pengolahan Air, BPPT, Jakarta 2002. Kualitas air minum dan dampaknya terhadap kesehatan,BPPT, Jakarta 2008. Teknologi Pengolahan Air Minum, BPPT, Jakarta

Slideshare.net, 2011. Bakteri-7794453 (dari penelusuran Google)

Sulistyandari, H., 2009, Faktor-faktor yang Berhubungandengan Kontaminasi Deterjen pada Air Minum Isi Ulang di Depot Air Minum di Kabupaten Kendal.

Tjokrokusumo, 2000, Pengantar Enjinering Lingkungan, STT. Lingkungan, Jogjakarta.

Wikipedia.Org, 2011. Virus (dari penelusuran www.Google.com ) 
